\title{
High-cell-density fermentation of Saccharomyces cerevisiae for the optimisation of mead production
}

\author{
A.P. Pereira ${ }^{\text {a,b }}$, A. Mendes-Ferreira a , J.M. Oliveira ${ }^{\text {c }}$, L.M. Estevinho ${ }^{\text {b }}$, A. Mendes-Faia ${ }^{\mathrm{a}, *}$ \\ a IBB-Institute for Biotechnology and Bioengineering, Centre of Genomics and Biotechnology, Universidade de Trás-os-Montes e Alto Douro, Apartado 1013, \\ 5001-801 Vila Real, Portugal

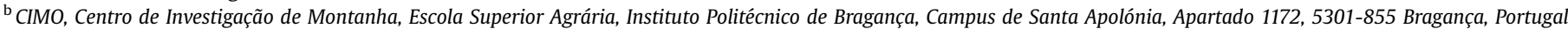 \\ ${ }^{\mathrm{C}}$ IBB-Institute for Biotechnology and Bioengineering, Centre of Biological Engineering, Universidade do Minho, 4710-057 Braga, Portugal
}

\section{A R T I C L E I N F O}

\section{Article history:}

Received 16 February 2012

Received in revised form

19 July 2012

Accepted 14 September 2012

Available online 25 September 2012

\section{Keywords:}

Aroma profile

Fermentation profile

Mead

Pitching rate

Saccharomyces cerevisiae

Yeast growth

\begin{abstract}
A B S T R A C T
Mead is a traditional drink that contains $8 \%-18 \%(\mathrm{v} / \mathrm{v})$ of ethanol, resulting from the alcoholic fermentation of diluted honey by yeasts. Mead fermentation is a time-consuming process and the quality of the final product is highly variable. Therefore, the present investigation had two main objectives: first, to determine the adequate inoculum size of two commercial wine-making strains of Saccharomyces cerevisiae for the optimisation of mead fermentation; and second, to determine if an increase in yeast pitching rates in batch fermentations altered the resulting aroma profiles. Minor differences were detected in the growth kinetics between the two strains at the lowest pitching rate. With increasing pitching rates net growth of the strain ICV D47 progressively decreased, whereas for the QA23 the increasing inoculum size had no influence on its net growth. The time required to reach the same stage of fermentation ranged from 24 to $96 \mathrm{~h}$ depending on the inoculum size. The final aroma composition was dependent on the yeast strain and inoculum size. Fourteen of the twenty-seven volatile compounds quantified could contribute to mead aroma and flavour because their concentrations rose above their respective thresholds. The formation of these compounds was particularly pronounced at low pitching rates, except in mead fermented by strain ICV D47, at $10^{6}$ CFUs/mL. The esters isoamyl acetate, ethyl octanoate and ethyl hexanoate were the major powerful odourants found in the meads. The results obtained in this study demonstrate that yeast strain and inoculum size can favourably impact mead's flavour and aroma profiles.
\end{abstract}

(c) 2012 Elsevier Ltd. All rights reserved.

\section{Introduction}

Mead is a traditional drink, containing $8 \%-18 \%(\mathrm{v} / \mathrm{v})$ of ethanol resulting from the alcoholic fermentation of diluted honey by yeasts. Honey production is an activity of significant economic importance in several regions of Portugal. New honey-based products such as mead must be developed to maintain apiculture as a viable industry. However, when mead is homemade, problems such as a lack of uniformity of the final products arise, probably due to the variability of honey composition between years, refermentation by yeasts or by acetic acid- and lactic acid-producing bacteria, which may increase volatile acidity and abnormal ester production and thus affect the organoleptic qualities of the final product (O'Connor-Cox and Ingledew, 1991).

\footnotetext{
* Corresponding author. Tel.: +351 259350554; fax: +351 259350480 .

E-mail address: afaia@utad.pt (A. Mendes-Faia).
}

Mead fermentation is a time-consuming process that often takes several months to complete, depending on the type of honey, yeast strain and honey-must composition (Navrátil et al., 2001). An important objective of mead makers is to reduce the fermentation time without decreasing the quality of their end products. Some studies of mead production optimisation have been performed. Pereira et al. (2009) achieved fermentations within roughly 8 days using dark and light honeys enriched with two different supplements. More recently, Mendes-Ferreira et al. (2010) optimised honey-must preparation for mead production by supplementing the honey-must with potassium tartrate, malic acid and diammonium phosphate (DAP) and were able to reduce the fermentation time to 11 days. Even under these improved conditions, the available sugars were not completely consumed by yeasts and a certain amount of residual assimilable nitrogen remained in all of the meads, even in controls in which no nitrogen was added. In addition, the density of yeast in colony forming units (CFUs) even under the 
most favourable conditions was never higher than $10^{7} \mathrm{CFUs} / \mathrm{mL}$, suggesting that there is something in honey-must that inhibits the growth of yeast.

It has been shown that significant time can be saved in the fermentation process by increasing the pitching rate, i.e., the amount of suspended yeast cells added to a batch fermenter (Verbelen et al., 2009a, b). However, an increase in the pitching rate could also have deleterious side effects on the fermentation performance or on the flavour profile of the final beverage (Verbelen et al., 2009a).

In this study, to further improve the mead fermentation process, the best formulation selected from a previous study (Mendes-Ferreira et al., 2010) was used to investigate the impact of the pitching rate on yeast fermentation performance as well as on the mead composition and the volatile aromatic compound production. The impact of higher inoculum size was assessed with two active dry wine yeast Saccharomyces cerevisiae strains. The strain QA23 was selected because it offers dependability under difficult wine-making conditions and it has low requirements for oxygen and assimilable nitrogen. The strain ICV D47 was used because it has a high fermentation rate, a low production of acetaldehyde and volatile acidity and because it is recommended for mead production. Further details about the strains are given in the website of yeast producer www. lallemand.com.

\section{Material and methods}

\subsection{Yeast strains}

S. cerevisiae Lalvin QA23 (Lallemand, Montreal, Canada) and S. cerevisiae Lalvin ICV D47 (Lallemand, Montreal, Canada) were used in this study as active wine dry yeasts.

\subsection{Honey}

In this study, dark honey purchased from a local beekeeper in the northeast region of Portugal was used. A palynological analysis of the honey was performed according to the acetolytic method (Pires et al., 2009) and it was determined that this multifloral honey was derived primarily from the pollen of Castanea spp. and Erica spp.

In accordance with requirements established in Portuguese legislation (Decreto-Lei $n^{\circ}$ 214/2003, of 18th September), the characteristics and satisfactory quality of the honey were assured through an analysis of the following parameters: moisture content, diastase index and hydroxymethylfurfural (HMF) content according to Gomes et al. (2010); pH, acidity and reducing sugars as described by Bogdanov et al. (1997); and electric conductivity and ash content as described by Sancho et al. (1991).

\subsection{Preparation of honey-must for fermentation}

To obtain an alcoholic beverage with approximately $11 \%$ of ethanol, honey was diluted in natural spring-water obtained in the market $(37 \% \mathrm{w} / \mathrm{v})$, and mixed to homogeneity as previously described (Mendes-Ferreira et al., 2010). After, any insoluble materials were removed from the mixture by centrifugation (2682 $\times \mathrm{g}$ for $30 \mathrm{~min}$; Eppendorf $5810 \mathrm{R}$ centrifuge) to obtain a clarified honey-must. Titrable acidity was adjusted with $5 \mathrm{~g} / \mathrm{L}$ of potassium tartrate (Sigma-Aldrich, St. Louis, USA) and $\mathrm{pH}$ was adjusted to 3.7 with malic acid (Merck, Darmstadt, Germany). The nitrogen content was adjusted to $267 \mathrm{mg} / \mathrm{L}$ with diammonium phosphate (DAP, BDH Prolabo, Leuven, Belgium). The parameters ${ }^{\circ} \mathrm{Brix}, \mathrm{pH}$, total acidity and assimilable nitrogen concentration were determined, prior and after the adjustments. The honey-musts were pasteurised at $65{ }^{\circ} \mathrm{C}$ for $10 \mathrm{~min}$ and then immediately cooled. No sulphur dioxide was added to the honeymusts.

\subsection{Inoculum preparation}

Starter cultures were prepared by rehydration of $10 \mathrm{~g}$ of active dry yeast into $100 \mathrm{~mL}$ of honey-must at $38{ }^{\circ} \mathrm{C}$ according to the manufacturer's instructions to obtain $10^{8} \mathrm{CFUs} / \mathrm{mL}$.

\subsection{Fermentation conditions and monitoring}

The appropriate amounts of inoculum were pitched into the honey-must to obtain five different pitching rates: (PR1) $1.5 \times 10^{5} \mathrm{CFUs} / \mathrm{mL}$, (PR2) $10^{6} \mathrm{CFUs} / \mathrm{mL}$, (PR3) $10^{7} \mathrm{CFUs} / \mathrm{mL}$, (PR4) $4 \times 10^{7}$ CFUs/mL and (PR5) $10^{8}$ CFUs/mL. All fermentations were carried out in triplicate using a previously described system (Mendes-Ferreira et al., 2010) that consisted of $250 \mathrm{~mL}$ flasks filled to $2 / 3$ of their volume and fitted with a side-arm port sealed with a rubber septum for anaerobic sampling. The flasks were maintained during alcoholic fermentation at $22{ }^{\circ} \mathrm{C}$ under permanent but moderate shaking ( $\left.120 \mathrm{rpm} \mathrm{min}^{-1}\right)$ mimicking real industrial environment. Aseptic sampling for assessing fermentation and growth parameters was performed using a syringe-type system as previously described (Mendes-Ferreira et al., 2009). Fermentations were daily monitored by weight loss as an estimate of $\mathrm{CO}_{2}$ production. At the same time, samples were collected and appropriately diluted for the measurement of their optical density at $640 \mathrm{~nm}$ in a UV-visible spectrometer (Unicam He $\lambda$ ios) and for counting their CFUs in solid Yeast Peptone Dextrose agar (YPD-20 g/L glucose, $10 \mathrm{~g} / \mathrm{L}$ peptone, $5 \mathrm{~g} / \mathrm{L}$ yeast extract and $20 \mathrm{~g} / \mathrm{L}$ agar) plates after incubation at $25^{\circ} \mathrm{C}$ for $48 \mathrm{~h}$. Determinations of reducing sugars were performed using the 3,5-dinitrosalicylic acid (DNS) method with glucose as the standard. At the end of alcoholic fermentation, samples were taken from all fermented media for culture dry weight determination as well as the analysis of several oenological parameters and the aroma profiles of the meads.

\subsection{Analyses performed at the end of fermentation}

The culture dry weight was determined from triplicate samples of $14 \mathrm{~mL}$ centrifuged in pre-weighed tubes at $3890 \times \mathrm{g}$ for $10 \mathrm{~min}$, washed twice with sterile deionised water, dried for $24 \mathrm{~h}$ at $100{ }^{\circ} \mathrm{C}$ and stored in a desiccator before weighing. The maximum fermentation rate was determined from the slope of the linear dependence of the steepest decline in weight at the corresponding time points.

The oenological parameters such as total sulphur dioxide $\left(\mathrm{SO}_{2}\right), \mathrm{pH}$, titratable acidity, volatile acidity and ethanol content were determined according to standard methods (Organisation Internationale de la Vigne et du Vin, 2006). Yeast assimilable nitrogen (YAN) was determined by formaldehyde method as described elsewhere (Aerny, 1996). After clarification, $10 \mathrm{~mL}$ of sample was transferred into a $50 \mathrm{~mL}$ beaker and diluted with $15 \mathrm{~mL}$ of water. The $\mathrm{pH}$ was adjusted to 8.1 with $\mathrm{NaOH} 0.1 \mathrm{M}$ and $2.5 \mathrm{~mL}$ of formaldehyde with $\mathrm{pH} 8.1$ was added. After $5 \mathrm{~min}$ the $\mathrm{pH}$ was adjusted again to 8.1 by titration with $\mathrm{NaOH} 0.05 \mathrm{M}$. Assimilable nitrogen was calculated using the formula:

YAN $(\mathrm{mg} / \mathrm{L})=[($ vol. $\mathrm{NaOH}) \times($ conc. $\mathrm{NaOH}) \times 14 \times 1000] /$ (sample volume). 


\subsection{Analysis of mead aromatic compounds}

Mead produced with five different yeast pitching rates was analysed for major volatile compounds by GC-FID and for minor volatile compounds by GC-MS. The major compounds in the samples were determined directly by the internal standard (4nonanol) method, taking into account the relative response of the detector for each analyte. Identification was made by a comparison of retention times with those of pure standard compounds. The minor volatile compounds were analysed after extraction with dichloromethane and quantified as 4-nonanol equivalents. Identification was made by a comparison of retention indices and mass spectra with those of pure standard compounds.

\subsubsection{Chromatographic analysis of major volatile compounds}

In a glass tube, $100 \mu \mathrm{L}$ of an ethanolic solution with $3640 \mathrm{mg} / \mathrm{L}$ of internal standard (4-nonanol, Merck, Darmstadt, Germany) was added to $5 \mathrm{~mL}$ of mead.

A Chrompack GC CP-9000 gas chromatograph equipped with a split/splitless injector, a flame ionisation detector (FID) and a capillary column CP-Wax 57 CB $(50 \mathrm{~m} \times 0.25 \mathrm{~mm}$; $0.2 \mu \mathrm{m}$ film thickness) was used. The temperature of the injector and detector were both set to $250{ }^{\circ} \mathrm{C}$ and the split ratio was $15 \mathrm{~mL} / \mathrm{min}$. The column temperature was initially held at $60^{\circ} \mathrm{C}$ for $5 \mathrm{~min}$ and then programmed to rise from $60{ }^{\circ} \mathrm{C}$ to $220^{\circ} \mathrm{C}$ at $3{ }^{\circ} \mathrm{C} / \mathrm{min}$ and finally maintained at $220^{\circ} \mathrm{C}$ for $10 \mathrm{~min}$. The carrier gas was special helium $4 \times$ (Praxair) at a flow rate of $1 \mathrm{~mL} / \mathrm{min}$ (125 kPa at the head of the column). The analysis was performed by the injection of $1 \mu \mathrm{L}$ of sample. The quantification of volatile compounds, after the determination the detector response factor for each analyte, was performed with the software Star-Chromatography Workstation version 6.41 (Varian) by comparing test compound retention times with those of pure standard compounds.

\subsubsection{Extraction of volatiles}

The extraction of mead minor volatiles was performed according to the method described by Oliveira et al. (2006). In a $10 \mathrm{~mL}$ culture tube (Pyrex, ref. 1636/26MP), $8 \mathrm{~mL}$ of mead clarified by centrifugation, $80 \mu \mathrm{L}$ of an ethanolic solution, $36.4 \mathrm{mg} / \mathrm{L}$ of an internal standard (4-nonanol, Merck, Darmstadt, Germany) and a magnetic stir bar $(22.2 \mathrm{~mm} \times 4.8 \mathrm{~mm})$ were added. The tube was sealed and extraction was accomplished by stirring the mead with $400 \mu \mathrm{L}$ of dichloromethane (Merck, Darmstadt, Germany) for 15 min with a magnetic stirrer. After cooling the solutions at $0{ }^{\circ} \mathrm{C}$ for $10 \mathrm{~min}$, the magnetic stir bar was removed and the organic phase was separated by centrifugation ( $\mathrm{RCF}=5118.5 \mathrm{~min}, 4^{\circ} \mathrm{C}$ ) and transferred into a vial with a Pasteur pipette. Finally, the aromatic extract was dried with anhydrous sodium sulphate (Merck, Darmstadt, Germany) and again transferred into a new vial.

\subsubsection{Chromatographic analysis of minor volatile compounds}

Minor volatile compounds were analysed by GC-MS using a gas chromatograph Varian 3800 with a 1079 injector and an ion-trap mass spectrometer Varian Saturn 2000. A $1 \mu \mathrm{L}$ injection was made in splitless mode (30 s) in a Varian Factor Four VF-WAXms (30 $\mathrm{m} \times 0.15 \mathrm{~mm} ; 0.15 \mu \mathrm{m}$ film thickness) column. The carrier gas was helium UltraPlus $5 \times(99.9999 \%)$ at a constant flow rate of $1.3 \mathrm{~mL} / \mathrm{min}$. The detector was set to electronic impact mode with an ionisation energy of $70 \mathrm{eV}$, a mass acquisition range from $35 \mathrm{~m} / \mathrm{z}$ to $260 \mathrm{~m} / \mathrm{z}$ and an acquisition interval of $610 \mathrm{~ms}$. The oven temperature was initially $60{ }^{\circ} \mathrm{C}$ for $2 \mathrm{~min}$ and then raised from $60{ }^{\circ} \mathrm{C}$ to $234{ }^{\circ} \mathrm{C}$ at a rate of $3{ }^{\circ} \mathrm{C} / \mathrm{min}$, raised from $234^{\circ} \mathrm{C}$ to $250{ }^{\circ} \mathrm{C}$ at $10^{\circ} \mathrm{C} /$ min and finally maintained at $250^{\circ} \mathrm{C}$ for $10 \mathrm{~min}$. The temperature of the injector was maintained at $250{ }^{\circ} \mathrm{C}$ during the analysis time and the split flow was maintained at $30 \mathrm{~mL} / \mathrm{min}$. The identification of compounds was performed using the software MS WorkStation version 6.6 (Varian) by comparing their mass spectra and retention indices with those of pure standard compounds. The minor compounds were quantified in terms of 4-nonanol equivalents.

\subsection{Statistical analysis}

An analysis of variance (ANOVA) with Type III sums of squares was performed using the GLM (General Linear Model procedure) of the SPSS software, version 17.0 (SPSS, Inc.). The fulfilment of the ANOVA requirement of homogeneity of variance was evaluated by means of Levene's test. All dependent variables were analysed using a one-way ANOVA with or without Welch correction, depending on whether the requirement of the homogeneity of variances was fulfilled. The main factor studied was the effect of pitching rate on the physicochemical characteristics and aromatic compounds of meads and if a statistically significant effect was found, the means were compared using Tukey's honestly significant difference multiple comparison test or Dunnett's T3 test, depending on whether equal variances could be assumed. All statistical tests were performed at a $5 \%$ significance level.

\section{Results and discussion}

Honey-must was diluted in spring water to obtain an alcoholic beverage with approximately $11 \%(\mathrm{v} / \mathrm{v})$ ethanol (Mendes-Ferreira et al., 2010). On the basis of the results obtained in previous assays, adjustments in assimilable nitrogen and $\mathrm{pH}$ were performed to optimise the yeasts' fermentation performance. To evaluate the impact of a high initial cell density on yeast fermentation performance and mead quality, four different pitching rates were used to obtain the following CFUs/mL: $10^{6}, 10^{7}, 4 \times 10^{7}$ and $10^{8}$ of $S$. cerevisiae. In parallel, a control fermentation was carried out with $1.5 \times 10^{5} \mathrm{CFUs} / \mathrm{mL}$ for comparison.

\subsection{Effect of pitching rate on yeast growth}

Fig. 1 contains the growth profiles of both strains QA23 and ICV D47 under the various conditions tested. As expected, the maximum cell biomass and the maximum number of CFUs were obtained at a pitching rate of $10^{8} \mathrm{CFUs} / \mathrm{mL}$ Yeast net growth, calculated by subtracting the initial CFU count from the maximum count, was higher for the lowest pitching rate $\left(1.5 \times 10^{5} \mathrm{CFUs} / \mathrm{mL}\right)$ for both strains (Fig. 2). The net growth of the strain ICV D47 progressively decreased with increasing pitching rates, in agreement with previous studies using high-cell-density fermentations for wine-making (Carrau et al., 2010) or brewing (Verbelen et al., 2009a). At the highest pitching rates $\left(4 \times 10^{7}\right.$ or $\left.10^{8} \mathrm{CFUs} / \mathrm{mL}\right)$, no detectable increase in yeast growth was observed, which could be explained by a cell-to-cell contact mechanism at high-cell-density of S. cerevisiae (Verbelen et al., 2009a). Contrary, the yeast net growth values were similar for the QA23 strain for the other pitching rates tested, $10^{6}, 10^{7}$ and $4 \times 10^{7} \mathrm{CFUs} / \mathrm{mL}$, suggesting that the increasing inoculum size had no influence on its net growth. Taken together these results, it seems that each strain responded differently to cell density being ICV D47 more sensitive to space limitation. Further studies are required to establish why one yeast strain is less able to compete for space than another.

Minor differences in growth kinetics were detected between the strains. At the three highest pitching rates $\left(10^{7}-10^{8} \mathrm{CFUs} / \mathrm{mL}\right)$, the number of CFUs of the strain ICV D47 remained constant throughout the fermentation; however, a slight increase was observed in the strain QA23 at pitching rates of $10^{7} \mathrm{CFUs} / \mathrm{mL}$ and $4 \times 10^{7}$ CFUs/mL. Moreover, at all pitching rates tested, the final CFUs of the strain ICV D47 were lower than those attained by the 
QA23
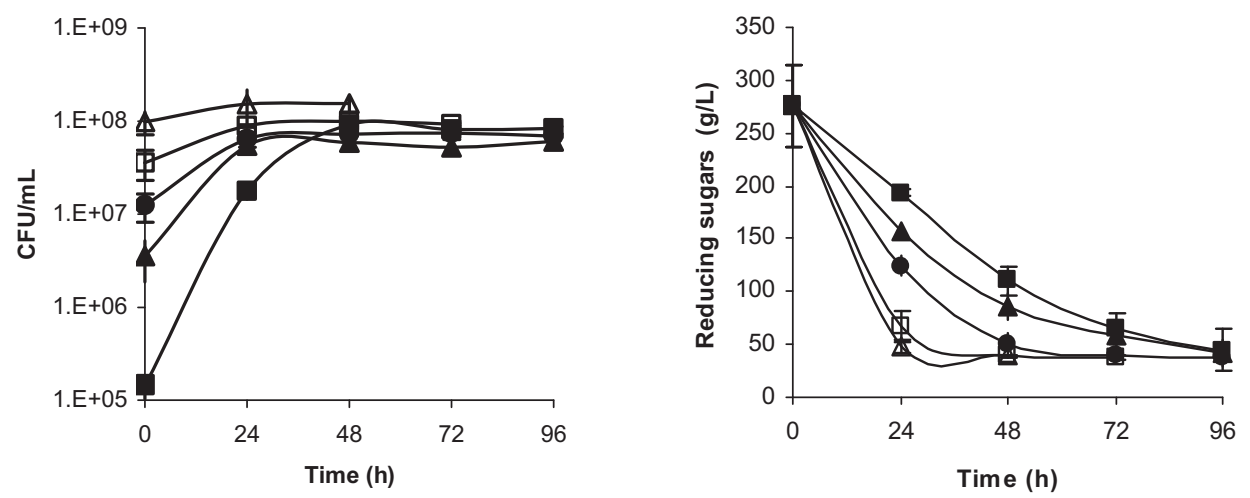

ICV D47
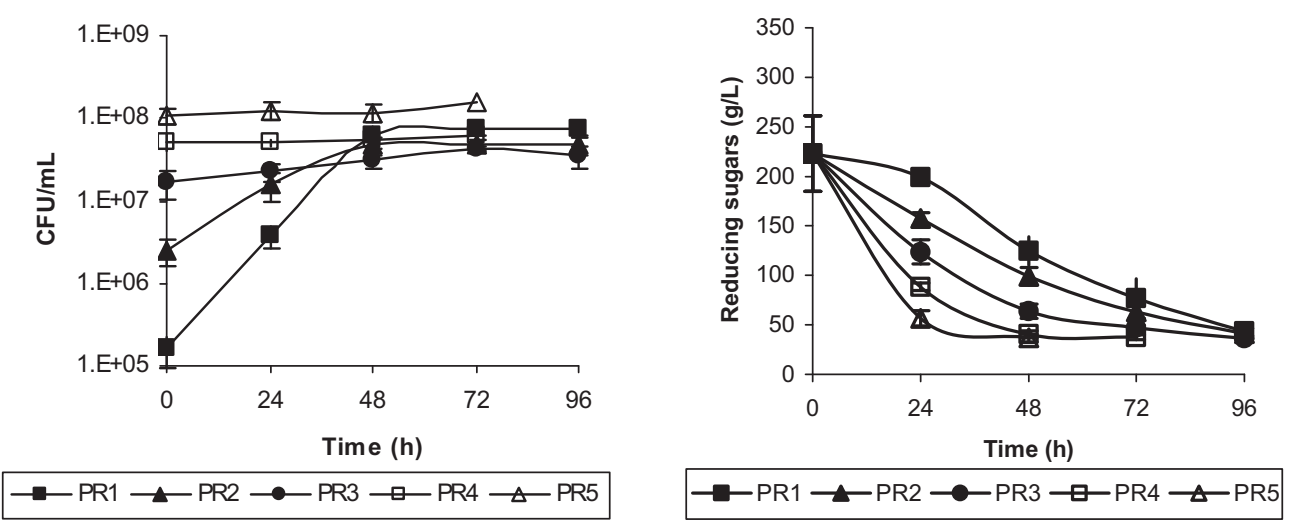

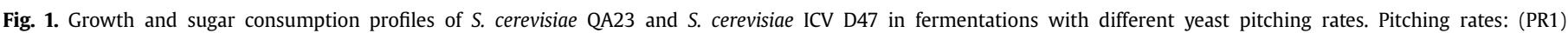
$1.5 \times 10^{5} \mathrm{CFUs} / \mathrm{mL}$, (PR2) $10^{6} \mathrm{CFUs} / \mathrm{mL}$, (PR3) $10^{7} \mathrm{CFUs} / \mathrm{mL}$, (PR4) $4 \times 10^{7} \mathrm{CFUs} / \mathrm{mL}$ and (PR5) $10^{8} \mathrm{CFUs} / \mathrm{mL}$.

strain QA23, as shown in Fig. 2. Although specific growth rates were similar in both strains, ICV D47 $\left(0.15 \mathrm{~h}^{-1}\right)$ and QA23 $\left(0.16 \mathrm{~h}^{-1}\right)$, at the lowest pitching rate, fermentation conducted by the former strain started later. Nevertheless, both strains entered into stationary phase $48 \mathrm{~h}$ after inoculation and the yeast cells remained viable after $168 \mathrm{~h}$ (results not shown). Entrance into stationary phase cannot be determined solely by the nitrogen depletion of the media because at the end of fermentation, some residual assimilable nitrogen remains in the media. Moreover, the amount of residual nitrogen was almost independent of the pitching rate or

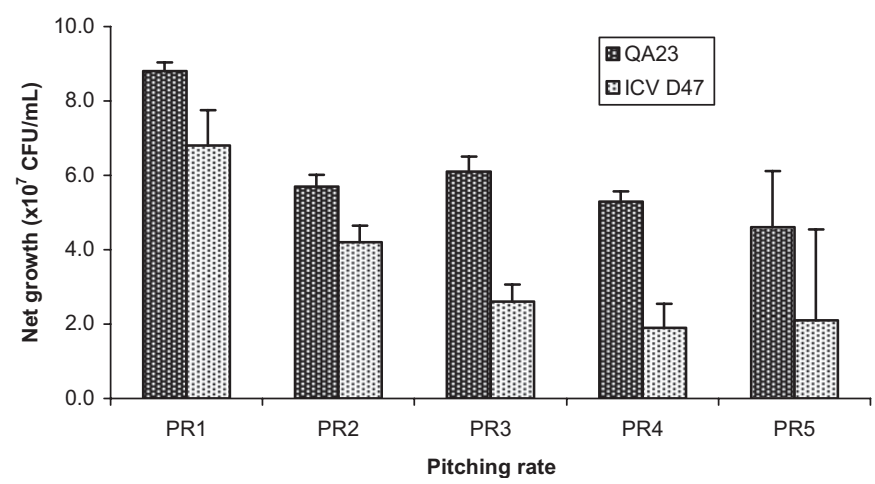

Fig. 2. Net yeast growth (the maximum CFU count minus the initial inoculum size) of mead fermentations with the yeast strains S. cerevisiae QA23 and S. cerevisiae ICV D47. Pitching rates: (PR1) $1.5 \times 10^{5} \mathrm{CFUs} / \mathrm{mL}$, (PR2) $10^{6} \mathrm{CFUs} / \mathrm{mL}$, (PR3) $10^{7} \mathrm{CFUs} / \mathrm{mL}$, (PR4) $4 \times 10^{7} \mathrm{CFUs} / \mathrm{mL}$ and (PR5) $10^{8} \mathrm{CFUs} / \mathrm{mL}$. yeast strain used. This observation has been reported by MendesFerreira et al. (2010) using the same honey-must formulation but a different yeast strain.

To verify whether the phenolic compounds were the inhibitors of yeast growth, the honey-musts were filtered through a SEPAK C18 cartridge to partially remove phenolic compounds before inoculation with the same strains and under the same conditions detailed above in the material and methods section. No differences in yeast growth characteristics or fermentative performance were detected, suggesting that probably other compounds present in honey are the interfering agents (results not shown).

\subsection{Effect of pitching rate on yeast fermentation profiles}

Fig. 1 contains the fermentation kinetics of S. cerevisiae QA23 and S. cerevisiae ICV D47 after pitching at five different rates. The time required to reach the same stage of fermentation in all pitching rates tested was approximately $96 \mathrm{~h}$ for the two smallest inocula, $72 \mathrm{~h}$ for the pitching rate of $10^{7} \mathrm{CFUs} / \mathrm{mL}, 48 \mathrm{~h}$ for the pitching rate of $4 \times 10^{7} \mathrm{CFUs} / \mathrm{mL}$ and approximately $24 \mathrm{~h}$ for the highest pitching condition. Therefore, a 100 -fold increase in the number of cells pitched reduced the fermentation time by 3 days, suggesting that the increase in pitching rate strongly decreased the duration of fermentation. Different results were obtained by Verbelen et al. (2009a), who achieved a 78\% reduction of fermentation time by increasing the pitching rate to fourfold of that used in conventional brewery fermentations $\left(20 \times 10^{6}\right.$ viable cells $\left./ \mathrm{mL}\right)$. In fact, in the present work, the fermentation time was reduced by 
Table 1

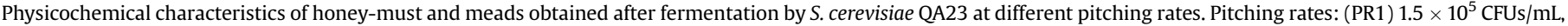
(PR2) $10^{6} \mathrm{CFUs} / \mathrm{mL}$, (PR3) $10^{7} \mathrm{CFUs} / \mathrm{mL}$, (PR4) $4 \times 10^{7} \mathrm{CFUs} / \mathrm{mL}$ and (PR5) $10^{8} \mathrm{CFUs} / \mathrm{mL}$. Data are the means of triplicate fermentations \pm S.D.

\begin{tabular}{|c|c|c|c|c|c|c|}
\hline Honey-musts & \multicolumn{4}{|c|}{ Prior adjustment } & \multicolumn{2}{|c|}{ After adjustment } \\
\hline $\mathrm{pH}$ & \multicolumn{4}{|c|}{$4.54 \pm 0.14$} & \multicolumn{2}{|c|}{$3.70 \pm 0.01$} \\
\hline${ }^{\circ}$ Brix & \multicolumn{4}{|c|}{$22.87 \pm 0.15$} & \multicolumn{2}{|c|}{$23.17 \pm 0.35$} \\
\hline 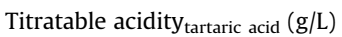 & \multicolumn{4}{|c|}{$0.70 \pm 0.09$} & \multicolumn{2}{|c|}{$4.64 \pm 1.07$} \\
\hline Initial nitrogen $_{\text {YAN }}(\mathrm{mg} / \mathrm{L})$ & \multicolumn{4}{|c|}{$49.00 \pm 7.00$} & \multicolumn{2}{|c|}{$277.67 \pm 14.15$} \\
\hline Meads & PR1 & PR2 & PR3 & PR4 & PR5 & $P$-value \\
\hline $\mathrm{pH}$ & $3.66 \pm 0.07$ & $3.71 \pm 0.07$ & $3.70 \pm 0.10$ & $3.70 \pm 0.13$ & $3.70 \pm 0.10$ & 0.964 \\
\hline Volatile acidity acetic acid $(\mathrm{g} / \mathrm{L})$ & $0.25 \pm 0.02^{\mathrm{a}}$ & $0.33 \pm 0.03^{a}$ & $0.63 \pm 0.04^{\mathrm{b}}$ & $1.02 \pm 0.12^{\mathrm{c}}$ & $1.38 \pm 0.16^{\mathrm{d}}$ & $<0.001$ \\
\hline Titratable acidity tartaric acid (g/L) & $6.74 \pm 0.62$ & $6.68 \pm 0.83$ & $7.18 \pm 1.01$ & $7.48 \pm 0.93$ & $7.76 \pm 0.88$ & 0.509 \\
\hline Final nitrogen $n_{\text {YAN }}(\mathrm{mg} / \mathrm{L})$ & $29.17 \pm 5.35$ & $32.67 \pm 2.02$ & $33.25 \pm 2.47$ & $37.33 \pm 2.02$ & $37.33 \pm 2.02$ & 0.049 \\
\hline Total $\mathrm{SO}_{2}(\mathrm{mg} / \mathrm{L})$ & $26.45 \pm 3.91$ & $24.32 \pm 4.62$ & $24.32 \pm 5.58$ & $23.04 \pm 4.43$ & $24.32 \pm 6.77$ & 0.949 \\
\hline Ethanol (\% vol) & $10.03 \pm 0.38$ & $10.33 \pm 0.12$ & $10.10 \pm 0.14$ & $10.33 \pm 0.23$ & $10.13 \pm 0.31$ & 0.555 \\
\hline Final reducing sugar $(\mathrm{g} / \mathrm{L})$ & $37.87 \pm 1.30$ & $40.52 \pm 0.70$ & $37.41 \pm 2.43$ & $37.87 \pm 1.56$ & $38.91 \pm 1.68$ & 0.214 \\
\hline
\end{tabular}

a-d Means within a line with different superscripts differ, $P<0.05$

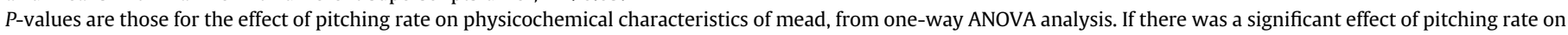
the analysed parameters, then the means were compared with Tukey's test because equal variances could be assumed $(P>0.05$ by means of the Levene test).

$34 \%$ at a fourfold higher yeast concentration. This result is in agreement with previous observations that in addition to exogenous nitrogen, other factors could account for reduced yeast activity in honey-must fermentations (Mendes-Ferreira et al., 2010). Given the difficulty in inocula preparation associated with the problems inherent in mead clarification and the accumulation of products or metabolic by-products to a growth-inhibitory level (Riesenberg and Guthke, 1999), high-cell-density fermentations may be of limited utility.

The fermentation profile of the strain IVC D47 at different pitching rates was largely similar to that of the strain QA23; however, a slight increase in fermentation time was observed (Fig. 1). For example, at the highest pitching rate of the strain ICV D47, the fermentation lasted for approximately $10 \mathrm{~h}$ more than with QA23.

The differences between the two strains were more obvious at the highest pitching rates (Fig. 2). Hence, young cells of strain ICV D47 were not generated in the high-cell-density fermentations. It is clear that the strain QA23 had fermentation and growth characteristics suitable to mead production, confirming its adaptation to the stressful conditions of wine-making. The strain QA23 consumed sugars more efficiently than did the strain ICV D47, especially at the smallest inoculum size $\left(1.5 \times 10^{5} \mathrm{CFUs} / \mathrm{mL}\right)$. In fact, the strain ICV D47 experienced longer lag phases and lower sugar consumption on the first day of fermentation.
For both strains and for all experimental conditions, although the fermentation had ceased, approximately $30-40 \mathrm{~g} / \mathrm{L}$ of residual sugar remained in the media (Fig. 1 and Tables 1 and 2). Residual sugars were determined by GC-MS and the results confirmed the presence of the non-fermentable sugars usually found in honeys (i.e., not glucose, fructose or sucrose, results not shown). In a previous study, very low residual glucose and fructose levels were detected in meads obtained from dark honey enriched with different supplements (Pereira et al., 2009).

\subsection{Effect of pitching rate on mead composition}

At the end of the alcoholic fermentations, samples were analysed to evaluate the meads' final compositions. Tables 1 and 2 present certain parameters recognised as essential for the composition and stability of meads, such as $\mathrm{pH}$, volatile and titratable acidity, $\mathrm{SO}_{2}$ concentration and ethanol concentration of the final meads fermented by QA23 and ICV D47, respectively. Both strains behaved similarly with respect to these characteristics, with the exceptions of $\mathrm{pH}$ and volatile acidity.

The $\mathrm{pH}$ values of the meads obtained with strain QA23 were identical to the honey-must (3.7) and remained constant during all fermentations, indicating that this parameter was not influenced by

Table 2

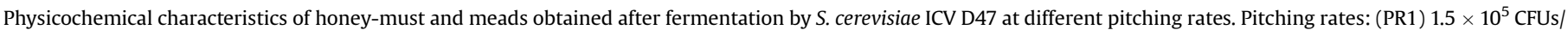
$\mathrm{mL}$, (PR2) $10^{6} \mathrm{CFUs} / \mathrm{mL}$, (PR3) $10^{7} \mathrm{CFUs} / \mathrm{mL}$, (PR4) $4 \times 10^{7} \mathrm{CFUs} / \mathrm{mL}$ and (PR5) $10^{8} \mathrm{CFUs} / \mathrm{mL}$. Data are the means of triplicate fermentations \pm S.D.

\begin{tabular}{|c|c|c|c|c|c|c|}
\hline Honey-musts & \multicolumn{4}{|c|}{ Prior adjustment } & \multicolumn{2}{|c|}{ After adjustment } \\
\hline $\mathrm{pH}$ & \multicolumn{4}{|c|}{$4.39 \pm 0.21$} & \multicolumn{2}{|c|}{$3.71 \pm 0.03$} \\
\hline${ }^{\circ}$ Brix & \multicolumn{4}{|c|}{$22.57 \pm 0.25$} & \multicolumn{2}{|c|}{$22.93 \pm 0.12$} \\
\hline Titratable acidity tartaric acid $_{(\mathrm{g} / \mathrm{L})}$ & \multicolumn{4}{|c|}{$0,69 \pm 0.06$} & \multicolumn{2}{|c|}{$4.08 \pm 1.03$} \\
\hline Initial nitrogen $_{\text {YAN }}(\mathrm{mg} / \mathrm{L})$ & \multicolumn{4}{|c|}{$64.17 \pm 29.35$} & \multicolumn{2}{|c|}{$281.17 \pm 15.78$} \\
\hline Meads & PR1 & PR2 & PR3 & PR4 & PR5 & $P$-value \\
\hline $\mathrm{pH}$ & $3.52 \pm 0.16$ & $3.54 \pm 0.16$ & $3.52 \pm 0.19$ & $3.49 \pm 0.20$ & $3.55 \pm 0.19$ & $0.996^{*}$ \\
\hline Volatile acidity acetic acid (g/L) & $0.39 \pm 0.08$ & $0.46 \pm 0.12$ & $0.53 \pm 0.17$ & $0.49 \pm 0.10$ & $0.60 \pm 0.03$ & $0.262^{*}$ \\
\hline Titratable acidity tartaric acid $(\mathrm{g} / \mathrm{L})$ & $6.35 \pm 1.02$ & $6.24 \pm 1.13$ & $6.48 \pm 1.12$ & $6.58 \pm 1.08$ & $6.70 \pm 0.93$ & $0.984^{*}$ \\
\hline Final nitrogen ${ }_{\text {YAN }}(\mathrm{mg} / \mathrm{L})$ & $31.50 \pm 9.26$ & $29.17 \pm 12.29$ & $36.17 \pm 22.77$ & $30.33 \pm 14.15$ & $42.00 \pm 12.62$ & $0.821^{*}$ \\
\hline Total $\mathrm{SO}_{2}(\mathrm{mg} / \mathrm{L})$ & $25.60 \pm 2.56$ & $25.60 \pm 3.39$ & $25.60 \pm 4.62$ & $22.61 \pm 2.66$ & $26.45 \pm 3.91$ & $0.716^{*}$ \\
\hline Ethanol (\% vol) & $9.70 \pm 0.26$ & $10.10 \pm 0.56$ & $10.03 \pm 0.38$ & $10.27 \pm 0.06$ & $10.37 \pm 0.06$ & $0.092^{* *}$ \\
\hline Final reducing sugar (g/L) & $35.27 \pm 2.86$ & $39.08 \pm 1.90$ & $37.06 \pm 3.16$ & $37.58 \pm 2.26$ & $38.68 \pm 2.44$ & $0.437^{*}$ \\
\hline
\end{tabular}

Lack of a superscript indicates no significant difference, $P>0.05$.

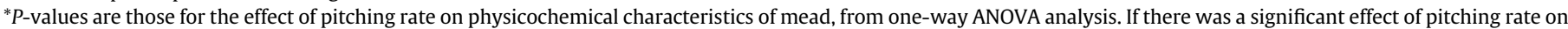
the analysed parameters, then the means were compared with Tukey's test because equal variances could be assumed $(P>0.05$ by means of the Levene test).

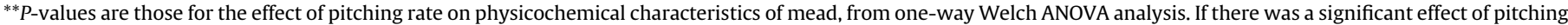

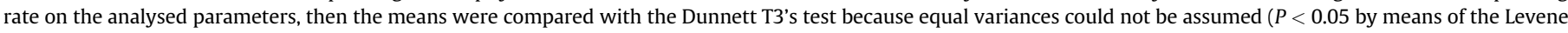
test). 
the pitching rate. On the contrary, meads obtained with strain ICV D47 demonstrated a slight decrease in $\mathrm{pH}$ to a range of 3.49-3.55.

The volatile acidity of meads fermented with QA23 ranged from 0.25 to $1.38 \mathrm{~g} / \mathrm{L}$ (Table 1 ) and increased with pitching rate. In contrast, the ICV D47 strain yielded slight variations in the volatile acidity among meads $(0.39-0.60 \mathrm{~g} / \mathrm{L})$, but again, the highest value was detected at the highest pitching rate. The results obtained with ICV D47 are very interesting, considering that volatile acidity should be minimised to avoid vinegar-like off-flavours (MendesFerreira et al., 2010). At the pitching rate of $10^{7} \mathrm{CFUs} / \mathrm{mL}$, the volatile acidity of mead fermented by strain QA23 (0.63 g/L) was lower than that obtained by Sroka and Tuszyński (2007) after $7 \mathrm{~d}$ of fermentation $(0.75 \mathrm{~g} / \mathrm{L})$ with other $\mathrm{S}$. cerevisiae strain. In fact, the production of acetic acid, which is quantitatively and sensorially the most important volatile fatty acid produced during alcoholic fermentation, is influenced by several factors, including yeast strain and inoculum size (Ugliano and Henschke, 2009).

The titratable acidity, total sulphur dioxide, alcohol content and final reducing sugars were similar in all of the meads fermented by either strain. Despite the increase in titratable acidity, the accentuation of which in meads fermented with QA23 indicates a high production of acids by this strain, no statistically significant differences were detected among the five pitching rates. The amounts of sulphur dioxide produced by the strain QA23 or by the strain ICV D47 were similar in all assays and were independent of the pitching rate. The total absence of $\mathrm{SO}_{2}$ is rare, even when sulphite is not added prior to fermentation, because yeast produce small quantities of this compound during fermentation that in certain cases can exceed $30 \mathrm{mg} / \mathrm{L}$ (Ribéreau-Gayon et al., 2000).

Despite the differences in net growth of QA23, the final ethanol content was nearly identical for all of the assays and varied from $10.03 \%(\mathrm{v} / \mathrm{v})$ at the lowest pitching rate $\left(1.5 \times 10^{5} \mathrm{CFUs} / \mathrm{mL}\right)$ to $10.33 \%$ at $10^{6}$ and $4 \times 10^{7} \mathrm{CFUs} / \mathrm{mL}$ (Table 1 ). The yeast strain ICV D47 produced less ethanol but similarly varied from $9.70 \%$ $\left(1.5 \times 10^{5} \mathrm{CFUs} / \mathrm{mL}\right)$ to $10.37 \%\left(10^{8} \mathrm{CFUs} / \mathrm{mL}\right)$. Based on the initial sugar levels it would be expected higher final ethanol levels. The discrepancy between the expected and the detected ethanol is explained by the residual non-fermentable sugars, approximately 35-40 g/L that remained in meads.

The residual nitrogen in all of the meads produced by both strains varied between 29.17 and $42.0 \mathrm{mg} / \mathrm{L}$ and there were no significant differences between the pitching rates tested. These results are in agreement with the concentrations of residual nitrogen detected by Mendes-Ferreira et al. (2010) using the same formulation of honey-must as in this study. Regardless of the inoculum size, the yeast assimilable nitrogen (YAN) consumed (initial nitrogen minus final nitrogen) was identical in all of the assays for both strains (Fig. 3). The estimated content of residual nitrogen may be the result of the quantification of nitrogen compounds not assimilable by the yeasts and in particular the amino acid proline. In fact, the formaldehyde method used here has a recovery rate of only $23 \%$ for proline (Filipe Ribeiro and MendesFaia, 2007); however, this amino acid represents $50-85 \%$ of the total nitrogen content of honey (Anklam, 1998).

The results of our mead composition analysis indicate not only that an increase in pitching rates is not recommended but also that the strain ICV D47 appears to be more suitable for the production of high quality meads, although the strain QA23 showed a better fermentation profile.

\subsection{Effect of pitching rate on mead aroma profile}

Seven major volatile compounds, including acetaldehyde, ethyl acetate, methanol, 1-propanol, 2-methyl-1-propanol, 2-methyl-1butanol and 3-methyl-1-butanol were analysed by GC-FID. The

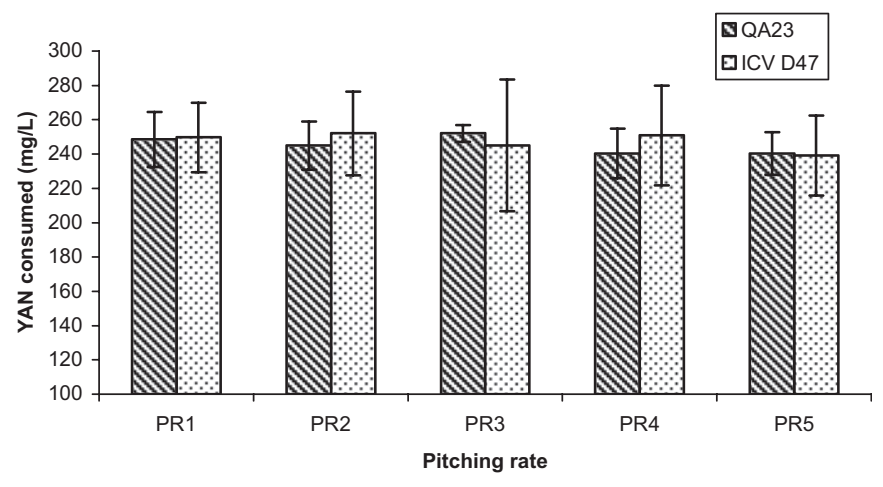

Fig. 3. Total yeast assimilable nitrogen (YAN) consumption (initial nitrogen minus final nitrogen) of mead fermentations with the yeast strains $S$. cerevisiae QA23 and S. cerevisiae ICV D47. Pitching rates: (PR1) $1.5 \times 10^{5} \mathrm{CFUs} / \mathrm{mL},(\mathrm{PR} 2) 10^{6} \mathrm{CFUs} / \mathrm{mL},(\mathrm{PR} 3)$ $10^{7} \mathrm{CFUs} / \mathrm{mL}$, (PR4) $4 \times 10^{7} \mathrm{CFUs} / \mathrm{mL}$ and (PR5) $10^{8} \mathrm{CFUs} / \mathrm{mL}$.

minor compounds quantified by GC-MS were ethyl butyrate, isoamyl acetate, ethyl hexanoate, ethyl lactate, 3-ethoxy-1-propanol, ethyl octanoate, isobutyric acid, butanoic acid, ethyl decanoate, 3(methylthio)-1-propanol, ethyl phenylacetate, 2-phenylethyl acetate, ethyl dodecanoate, hexanoic acid, 2-phenylethanol, octanoic acid, 4-vinylguaicol, decanoic acid, 4-vinylphenol and dodecanoic acid.

The effects of the pitching rate and the strain on mead volatile aromatic composition are presented in Table 3 for strain QA23 and in Table 4 for strain ICV D47. A total of twenty-seven fermentative aroma compounds which contribute to the sensorial qualities of alcoholic beverages, including alcohols, esters, volatile phenols, volatile fatty acids and carbonyl compounds were identified and quantified in these meads.

Meads obtained with different pitching rates and fermented by the two strains showed quantitative differences in aroma profiles, confirming the contribution of both yeast metabolism and inoculum size on the sensory characteristics of meads. In general, the total concentration of volatile compounds increased with increasing pitching rate, except for the lowest pitching rate $\left(1.5 \times 10^{5} \mathrm{CFUs} / \mathrm{mL}\right)$ and was higher in meads inoculated with strain ICV D47.

Alcohols were quantitatively the most abundant volatile compounds in all of the meads, confirming the importance of this group of volatile compounds produced by yeast during alcoholic fermentation (Ugliano and Henschke, 2009). Overall, we observed that increasing inoculum size led to higher concentration of alcohols. Our results are in agreement with those of Mateo et al. (2001), Erten et al. (2006) and Verbelen et al. (2009a, b), who studied the influence of yeast inoculum size on the fermentation performance and the volatile compound formation of wine and beer. The concentration of alcohols was below $300 \mathrm{mg} / \mathrm{L}$ in all of our meads, representing values considered desirable for increasing the complexity of wines (Ugliano and Henschke, 2009; Mateo et al., 2001). Quantitatively, the major alcohol in all of the meads was 3-methyl-1-butanol (Tables 3 and 4). There are few studies of mead aroma composition; however, our results are in accord with those of Mendes-Ferreira et al. (2010), who verified that the alcohol 3methyl-1-butanol was the major compound quantified in mead obtained with the same formulation used in our work, at a concentration of approximately $140 \mathrm{mg} / \mathrm{L}$. Similar concentrations of this compound were obtained in our work, irrespective of the yeast strain used. The concentrations of 1-propanol, 2-methyl-1propanol and 2-methyl-1-butanol increased with increasing pitching rates, except for the two lowest inoculum sizes $\left(1.5 \times 10^{5} \mathrm{CFUs} / \mathrm{mL}\right.$ and $\left.10^{6} \mathrm{CFUs} / \mathrm{mL}\right)$. Verbelen et al. (2008), 
Table 3

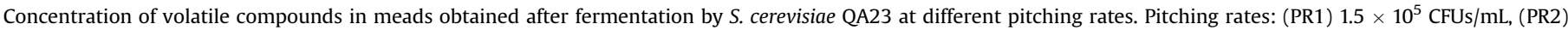
$10^{6} \mathrm{CFUs} / \mathrm{mL}$, (PR3) $10^{7} \mathrm{CFUs} / \mathrm{mL}$, (PR4) $4 \times 10^{7} \mathrm{CFUs} / \mathrm{mL}$ and (PR5) $10^{8} \mathrm{CFUs} / \mathrm{mL}$. Data are the means of triplicate fermentations \pm S.D.

\begin{tabular}{|c|c|c|c|c|c|c|}
\hline & PR1 & PR2 & PR3 & PR4 & PR5 & $P$-value \\
\hline \multicolumn{7}{|l|}{ Alcohols (mg/L) } \\
\hline 3-Methyl-1-butanol & $167.92 \pm 5.53^{b}$ & $133.64 \pm 10.43^{\mathrm{a}}$ & $128.45 \pm 9.64^{\mathrm{a}}$ & $117.57 \pm 11.71^{\mathrm{a}}$ & $122.90 \pm 9.71^{\mathrm{a}}$ & $0.001^{*}$ \\
\hline 2-Methyl-1-propanol & $22.52 \pm 2.33^{\mathrm{a}}$ & $19.90 \pm 2.81^{\mathrm{a}}$ & $27.99 \pm 2.96^{\mathrm{a}}$ & $41.24 \pm 8.14^{\mathrm{ab}}$ & $62.57 \pm 1.26^{b}$ & $<0.001^{* *}$ \\
\hline 2-Methyl-1-butanol & $21.48 \pm 1.02^{\mathrm{a}}$ & $16.16 \pm 0.98^{\mathrm{a}}$ & $22.56 \pm 3.27^{\mathrm{ab}}$ & $28.33 \pm 2.62^{\mathrm{bc}}$ & $31.75 \pm 3.53^{c}$ & $<0.001^{*}$ \\
\hline 1-Propanol & $17.95 \pm 1.69^{\mathrm{a}}$ & $14.93 \pm 1.01^{\mathrm{a}}$ & $22.11 \pm 3.03^{\mathrm{ab}}$ & $30.53 \pm 5.29^{\mathrm{b}}$ & $40.13 \pm 3.62^{c}$ & $<0.001^{*}$ \\
\hline 2-Phenylethanol & $12.84 \pm 1.38^{c}$ & $12.47 \pm 4.44^{\mathrm{bc}}$ & $8.05 \pm 0.47^{\mathrm{abc}}$ & $6.97 \pm 1.20^{\mathrm{ab}}$ & $5.76 \pm 0.22^{\mathrm{a}}$ & $0.007^{*}$ \\
\hline Methanol & $5.36 \pm 4.65$ & $2.62 \pm 0.45$ & $3.44 \pm 0.50$ & $4.87 \pm 0.73$ & $3.46 \pm 0.95$ & $0.091^{* *}$ \\
\hline 3-Ethoxy-1-propanol & $0.08 \pm 0.01$ & $0.15 \pm 0.11$ & $0.08 \pm 0.01$ & $0.10 \pm 0.03$ & $0.08 \pm 0.01$ & $0.773^{* *}$ \\
\hline 3-(Methylthio)-1-propanol & $0.06 \pm 0.01$ & $0.07 \pm 0.03$ & $0.06 \pm 0.01$ & $0.07 \pm 0.01$ & $0.08 \pm 0.01$ & $0.089^{* *}$ \\
\hline Total & $248.21 \pm 7.96$ & $199.93+11.77$ & $212.75+11.05$ & $229.68 \pm 15.49$ & $266.75 \pm 11.06$ & \\
\hline \multicolumn{7}{|l|}{ Esters (mg/L) } \\
\hline Ethyl acetate & $27.15 \pm 0.80^{\mathrm{a}}$ & $25.02 \pm 1.67^{\mathrm{a}}$ & $23.58 \pm 1.97^{\mathrm{a}}$ & $27.21 \pm 3.17^{\mathrm{a}}$ & $35.19 \pm 2.14^{b}$ & $<0.001^{*}$ \\
\hline Isoamyl acetate & $1.03 \pm 0.09^{\mathrm{b}}$ & $1.02 \pm 0.27^{\mathrm{ab}}$ & $0.47 \pm 0.08^{a}$ & $0.21 \pm 0.01^{\mathrm{a}}$ & $0.23 \pm 0.02^{\mathrm{a}}$ & $<0.001^{* *}$ \\
\hline 2-Phenylethyl acetate & $0.60 \pm 0.06^{\mathrm{b}}$ & $0.50 \pm 0.15^{\mathrm{ab}}$ & $0.15 \pm 0.03^{\mathrm{a}}$ & $0.06 \pm 0.01^{\mathrm{a}}$ & $0.06 \pm 0.00^{\mathrm{a}}$ & $0.001^{* *}$ \\
\hline Ethyl octanoate & $0.48 \pm 0.09^{\mathrm{ab}}$ & $0.54 \pm 0.12^{\mathrm{ab}}$ & $0.23 \pm 0.02^{\mathrm{b}}$ & $0.14 \pm 0.03^{\mathrm{ab}}$ & $0.10 \pm 0.02^{\mathrm{a}}$ & $0.002^{* *}$ \\
\hline Ethyl hexanoate & $0.34 \pm 0.07^{\mathrm{ab}}$ & $0.27 \pm 0.07^{\mathrm{ab}}$ & $0.12 \pm 0.01^{\mathrm{b}}$ & $0.07 \pm 0.02^{\mathrm{ab}}$ & $0.05 \pm 0.01^{\mathrm{a}}$ & $0.004^{* *}$ \\
\hline Ethyl decanoate & $0.30 \pm 0.10^{\mathrm{ab}}$ & $0.29 \pm 0.06^{\mathrm{ab}}$ & $0.10 \pm 0.01^{\mathrm{b}}$ & $0.04 \pm 0.01^{\mathrm{a}}$ & $0.022 \pm 0.003^{\mathrm{a}}$ & $0.002^{* *}$ \\
\hline Ethyl butyrate & $0.12 \pm 0.03$ & $0.07 \pm 0.01$ & $0.05 \pm 0.01$ & $0.08 \pm 0.05$ & $0.10 \pm 0.05$ & $0.064^{* *}$ \\
\hline Ethyl dodecanoate & $0.07 \pm 0.02$ & $0.07 \pm 0.02$ & $0.007 \pm 0.002$ & tr. & tr. & - \\
\hline Ethyl lactate & $0.023 \pm 0.003$ & $0.03 \pm 0.02$ & $0.020 \pm 0.005$ & $0.017 \pm 0.008$ & $0.013 \pm 0.004$ & $0.257^{* *}$ \\
\hline Ethyl phenylacetate & $0.004 \pm 0.001$ & $0.003 \pm 0.000$ & $0.003 \pm 0.001$ & $0.004 \pm 0.002$ & $0.003 \pm 0.000$ & $0.682^{* *}$ \\
\hline Total & $30.13 \pm 0.83$ & $27.81 \pm 1.71$ & $24.72 \pm 1.97$ & $27.83 \pm 3.17$ & $35.76 \pm 2.14$ & \\
\hline \multicolumn{7}{|l|}{ Volatile phenols $(\mu \mathrm{g} / \mathrm{L})$} \\
\hline 4-Vinylphenol & $195.17 \pm 29.68^{\mathrm{ab}}$ & $178.63 \pm 49.50^{\mathrm{ab}}$ & $144.72 \pm 6.20^{\mathrm{a}}$ & $96.49 \pm 17.00^{\mathrm{ab}}$ & $112.61 \pm 8.72^{b}$ & $0.016^{* *}$ \\
\hline 4-Vinylguaiacol & $100.67 \pm 9.17^{c}$ & $85.13 \pm 11.68^{\mathrm{bc}}$ & $67.52 \pm 3.85^{\mathrm{ab}}$ & $50.92 \pm 15.19^{a}$ & $55.02 \pm 5.31^{\mathrm{a}}$ & $0.001^{*}$ \\
\hline Total & $295.84 \pm 31.07$ & $263.76 \pm \mathbf{5 0 . 8 6}$ & $212.24 \pm 7.30$ & $147.41 \pm 22.80$ & $167.63 \pm 10.21$ & \\
\hline \multicolumn{7}{|l|}{ Volatile fatty acids $(\mu \mathrm{g} / \mathrm{L})$} \\
\hline Octanoic acid & $2158.77 \pm 124.05^{c}$ & $1622.81 \pm 509.27^{\mathrm{abc}}$ & $852.45 \pm 118.22^{b}$ & $516.75 \pm 174.10^{\mathrm{ab}}$ & $308.85 \pm 45.82^{\mathrm{a}}$ & $<0.001^{* *}$ \\
\hline Decanoic acid & $1028.31 \pm 339.35^{\mathrm{ab}}$ & $540.88 \pm 160.01^{\mathrm{ab}}$ & $222.08 \pm 23.05^{b}$ & $82.29 \pm 42.77^{\mathrm{ab}}$ & $27.93 \pm 6.04^{\mathrm{a}}$ & $0.001^{* *}$ \\
\hline Hexanoic acid & $600.66 \pm 78.68^{c}$ & $567.37 \pm 202.10^{\mathrm{abc}}$ & $272.35 \pm 28.96^{\mathrm{b}}$ & $155.67 \pm 37.14^{\mathrm{ab}}$ & $118.25 \pm 7.04^{a}$ & $0.002^{* *}$ \\
\hline Isobutyric acid & $24.99 \pm 11.44^{\mathrm{ab}}$ & $33.88 \pm 20.73^{\mathrm{a}}$ & $44.15 \pm 9.73^{\mathrm{ab}}$ & $102.77 \pm 31.71^{\mathrm{ab}}$ & $213.19 \pm 45.47^{\mathrm{b}}$ & $0.013^{* *}$ \\
\hline Dodecanoic acid & $55.39 \pm 28.47$ & $21.91 \pm 11.43$ & $17.40 \pm 1.79$ & $17.60 \pm 1.26$ & $15.95 \pm 3.64$ & 0.452 \\
\hline Butanoic acid & $16.90 \pm 4.40^{\mathrm{ab}}$ & $20.24 \pm 8.75^{\mathrm{ab}}$ & $12.04 \pm 179^{a}$ & $15.50 \pm 3.82^{\mathrm{ab}}$ & $26.84 \pm 4.35^{\mathrm{b}}$ & $0.047^{*}$ \\
\hline $\begin{array}{l}\text { Total } \\
\text { Carbonyl compounds (mg/L) }\end{array}$ & $3885.02 \pm 371.08$ & $\mathbf{2 8 0 7 . 0 8} \pm \mathbf{5 7 1 . 3 5}$ & $1420.48 \pm 124.28$ & $890.58 \pm 185.85$ & $711.00 \pm 65.46$ & \\
\hline Acetaldehyde & $7.12 \pm 2.38$ & $6.27 \pm 0.49$ & $9.81 \pm 3.00$ & $7.91 \pm 2.83$ & $7.53 \pm 1.28$ & $0.429^{*}$ \\
\hline
\end{tabular}

tr. - traces. a-d Means within a line with different superscripts differ, $P<0.05$. Lack of a superscript indicates no significant difference, $P>0.05$.

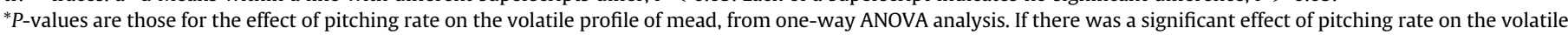
compounds data, then the means were compared with Tukey's test because equal variances could be assumed $(P>0.05$ by means of the Levene test).

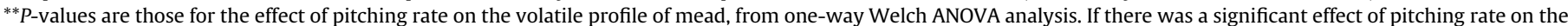

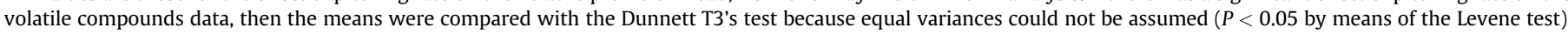

working in brewing, also detected an increase in higher alcohol formation when using high pitching rates. No differences in 3methyl-1-butanol were observed in meads fermented at different pitching rates by the strain ICV D47, whereas a higher concentration of this alcohol was detected only at the lowest pitching rate $\left(1.5 \times 10^{5} \mathrm{CFUs} / \mathrm{mL}\right)$ with the strain QA23. Different results were obtained by Mateo et al. (2001), Erten et al. (2006), Verbelen et al. (2008) and Verbelen et al. (2009a), who indicated a direct dependence of the concentration of that compound on inoculum size.

Esters represented the most diverse group with ten compounds quantified. Their concentrations varied between 18 and $35 \mathrm{mg} / \mathrm{L}$, with the highest ester concentrations found in the meads fermented by the strain QA23. No clear trend was observed between the total concentration of esters and the pitching rate, although minor differences were observed among meads fermented at different pitching rates. Ethyl acetate was the major ester compound quantified, although at lower concentrations than those detected by Mendes-Ferreira et al. (2010) for the same alcoholic beverage. Similar concentrations were detected by Verbelen et al. (2009a) in beer. Other authors showed that ester levels were negatively influenced by higher pitching rates (Verbelen et al., 2008). A similar result was observed in this study for isoamyl acetate and 2-phenylethyl acetate, compounds with fruity and flowery flavours, respectively. Also Erten et al. (2006) found an inverse correlation between inoculum size and the concentration of isoamyl acetate. In fact, the highest concentration of the ester was found in wines fermented with the lowest cell density $\left(10^{5}\right.$ cells $\left./ \mathrm{mL}\right)$.

Volatile phenols are predominantly produced by yeast during fermentation and are known for their contribution to off-flavours (Swiegers et al., 2005). Two phenols and in particular 4-vinylphenol, were identified in meads at concentrations below their respective detection thresholds. There were no relevant differences between the two strains with respect to these compounds; however, increasing the pitching rate resulted in a slight decrease in their concentration.

The most abundant of six volatile fatty acids (VFA) quantified was octanoic acid and the amount of this compound was independent of the yeast strain. In general, the concentration of VFA decreased with increasing pitching rate, except for the strain ICV D47. At the lowest pitching rates, $1.5 \times 10^{5} \mathrm{CFUs} / \mathrm{mL}$ and $10^{6} \mathrm{CFUs/}$ $\mathrm{mL}$, the strain QA23 produced more VFA than did the strain ICV D47, whereas the opposite was observed at higher pitching rates. Two of the six compounds quantified, hexanoic and octanoic acids, were above their respective detection thresholds. The results obtained here are in agreement with those of Mendes-Ferreira et al. (2010), who verified that octanoic acid was quantitatively the major volatile fatty acid founds in meads, followed by hexanoic and decanoic acids. Acetaldehyde was the only carbonyl compound quantified in meads obtained after fermentation with strains QA23 and ICV D47. 
Table 4

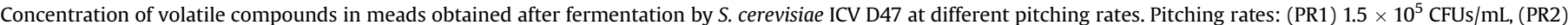
$10^{6} \mathrm{CFUs} / \mathrm{mL}$, (PR3) $10^{7} \mathrm{CFUs} / \mathrm{mL}$, (PR4) $4 \times 10^{7} \mathrm{CFUs} / \mathrm{mL}$ and (PR5) $10^{8} \mathrm{CFUs} / \mathrm{mL}$. Data are the means of triplicate fermentations \pm S.D.

\begin{tabular}{|c|c|c|c|c|c|c|}
\hline & PR1 & PR2 & PR3 & PR4 & PR5 & $P$-value \\
\hline \multicolumn{7}{|l|}{ Alcohols (mg/L) } \\
\hline 3-Methyl-1-butanol & $150.34 \pm 28.98$ & $139.83 \pm 9.45$ & $126.24 \pm 14.83$ & $146.00 \pm 2.47$ & $165.18 \pm 13.76$ & $0.236^{* *}$ \\
\hline 2-Methyl-1-propanol & $19.86 \pm 1.32^{\mathrm{a}}$ & $20.68 \pm 1.19^{a}$ & $24.65 \pm 4.20^{\mathrm{a}}$ & $41.70 \pm 3.27^{b}$ & $74.73 \pm 17.30^{\mathrm{ab}}$ & $0.002^{* *}$ \\
\hline 2-Methyl-1-butanol & $21.28 \pm 4.52^{\mathrm{a}}$ & $19.86 \pm 2.32^{\mathrm{a}}$ & $23.93 \pm 6.06^{\mathrm{a}}$ & $34.67 \pm 2.96^{b}$ & $35.54 \pm 2.84^{\mathrm{b}}$ & $0.001^{*}$ \\
\hline 1-Propanol & $18.66 \pm 1.49^{\mathrm{a}}$ & $22.76 \pm 2.47^{\mathrm{a}}$ & $32.62 \pm 0.97^{b}$ & $36.60 \pm 5.99^{b}$ & $52.53 \pm 2.02^{c}$ & $<0.001^{*}$ \\
\hline 2-Phenylethanol & $12.68 \pm 1.03^{b}$ & $11.07 \pm 0.45^{\mathrm{b}}$ & $7.62 \pm 1.19^{a}$ & $7.86 \pm 0.80^{\mathrm{a}}$ & $7.95 \pm 1.55^{\mathrm{a}}$ & $<0.001^{*}$ \\
\hline Methanol & $4.08 \pm 0.04$ & $4.67 \pm 0.85$ & $8.94 \pm 7.69$ & $18.40 \pm 25.28$ & $5.48 \pm 1.85$ & $0.545^{* *}$ \\
\hline 3-(Methylthio)-1-propanol & $0.09 \pm 0.01^{\mathrm{ab}}$ & $0.07 \pm 0.01^{\mathrm{a}}$ & $0.07 \pm 0.03^{\mathrm{a}}$ & $0.15 \pm 0.04^{\mathrm{b}}$ & $0.24 \pm 0.04^{c}$ & $<0.001^{*}$ \\
\hline 3-Ethoxy-1-propanol & $0.004 \pm 0.001$ & $0.010 \pm 0.002$ & $0.007 \pm 0.001$ & $0.008 \pm 0.003$ & $0.009 \pm 0.003$ & $0.080^{*}$ \\
\hline Total & $226.98 \pm 29.42$ & $218.95 \pm 10.15$ & $224.07 \pm 18.33$ & $285.38 \pm 26.48$ & $341.64 \pm 22.51$ & \\
\hline \multicolumn{7}{|l|}{ Esters (mg/L) } \\
\hline Ethyl acetate & $22.73 \pm 1.21$ & $25.76 \pm 4.18$ & $21.36 \pm 1.40$ & $17.91 \pm 3.25$ & $20.24 \pm 3.39$ & $0.074^{*}$ \\
\hline Isoamyl acetate & $1.34 \pm 0.24^{\mathrm{ab}}$ & $1.26 \pm 0.15^{\mathrm{b}}$ & $0.56 \pm 0.14^{\mathrm{a}}$ & $0.23 \pm 0.02^{\mathrm{a}}$ & $0.18 \pm 0.02^{\mathrm{a}}$ & $0.001^{* *}$ \\
\hline 2-Phenylethyl acetate & $0.69 \pm 0.15^{\mathrm{ab}}$ & $0.57 \pm 0.03^{b}$ & $0.14 \pm 0.03^{\mathrm{a}}$ & $0.08 \pm 0.01^{\mathrm{a}}$ & $0.08 \pm 0.01^{\mathrm{a}}$ & $<0.001^{* *}$ \\
\hline Ethyl octanoate & $0.39 \pm 0.09^{\mathrm{ab}}$ & $0.44 \pm 0.06^{\mathrm{ab}}$ & $0.32 \pm 0.03^{b}$ & $0.23 \pm 0.01^{\mathrm{ab}}$ & $0.172 \pm 0.003^{\mathrm{a}}$ & $0.003^{* *}$ \\
\hline Ethyl hexanoate & $0.21 \pm 0.03^{\mathrm{bc}}$ & $0.23 \pm 0.01^{\mathrm{c}}$ & $0.17 \pm 0.05^{\mathrm{abc}}$ & $0.095 \pm 0.003^{\mathrm{ab}}$ & $0.08 \pm 0.01^{\mathrm{a}}$ & $<0.001^{* *}$ \\
\hline Ethyl decanoate & $0.11 \pm 0.02^{\mathrm{ab}}$ & $0.14 \pm 0.04^{\mathrm{b}}$ & $0.09 \pm 0.03^{\mathrm{ab}}$ & $0.05 \pm 0.02^{\mathrm{a}}$ & $0.04 \pm 0.01^{\mathrm{a}}$ & $0.005^{*}$ \\
\hline Ethyl butyrate & $0.07 \pm 0.01$ & $0.12 \pm 0.07$ & $0.06 \pm 0.02$ & $0.07 \pm 0.03$ & $0.06 \pm 0.05$ & $0.738^{* *}$ \\
\hline Ethyl lactate & $0.02 \pm 0.01$ & $0.022 \pm 0.004$ & $0.019 \pm 0.004$ & $0.017 \pm 0.006$ & $0.013 \pm 0.001$ & $0.121^{*}$ \\
\hline Ethyl dodecanoate & $0.01 \pm 0.02$ & $0.04 \pm 0.01$ & tr. & tr. & tr. & - \\
\hline Ethyl phenylacetate & $0.003 \pm 0.001$ & $0.004 \pm 0.000$ & $0.003 \pm 0.001$ & $0.003 \pm 0.001$ & $0.013 \pm 0.001$ & $0.231^{*}$ \\
\hline Total & $25.59 \pm 1.24$ & $28.57 \pm 4.19$ & $22.73 \pm 1.41$ & $18.68+3.25$ & $20.87 \pm 3.39$ & \\
\hline \multicolumn{7}{|l|}{ Volatile phenols $(\mu \mathrm{g} / \mathrm{L})$} \\
\hline 4-Vinylphenol & $160.07 \pm 2.49^{\mathrm{bd}}$ & $166.24 \pm 13.53^{\mathrm{d}}$ & $155.31 \pm 21.32^{\mathrm{cd}}$ & $74.55 \pm 0.84^{\mathrm{ac}}$ & $67.80 \pm 21.90^{\mathrm{ab}}$ & $<0.001^{* *}$ \\
\hline 4-Vinylguaiacol & $89.39 \pm 10.15^{c}$ & $103.00 \pm 18.33^{\mathrm{abc}}$ & $87.44 \pm 14.35^{b c}$ & $31.23 \pm 1.15^{\mathrm{ab}}$ & $29.83 \pm 7.12^{\mathrm{a}}$ & $0.003^{* *}$ \\
\hline Total & $249.46 \pm 10.45$ & $269.24 \pm 22.78$ & $242.76 \pm 25.70$ & $105.78 \pm 1.42$ & $97.63 \pm 23.03$ & \\
\hline \multicolumn{7}{|l|}{ Volatile fatty acids $(\mu \mathrm{g} / \mathrm{L})$} \\
\hline Octanoic acid & $1344.51 \pm 239.84$ & $1869.02 \pm 903.08$ & $901.17 \pm 226.76$ & $657.89 \pm 197.15$ & $441.05 \pm 54.43$ & $0.020^{* *}$ \\
\hline Hexanoic acid & $420.61 \pm 27.85^{c}$ & $448.50 \pm 19.92^{c}$ & $308.74 \pm 12.43^{b}$ & $193.94 \pm 57.86^{\mathrm{ab}}$ & $167.74 \pm 11.50^{\mathrm{a}}$ & $<0.001^{* *}$ \\
\hline Decanoic acid & $401.86 \pm 62.45^{c}$ & $374.05 \pm 66.56^{c}$ & $224.95 \pm 69.15^{\mathrm{b}}$ & $108.92 \pm 38.57^{\mathrm{ab}}$ & $49.16 \pm 12.08^{a}$ & $<0.001^{*}$ \\
\hline Isobutyric acid & $21.95 \pm 5.39$ & $36.29 \pm 1.87$ & $61.55 \pm 16.99$ & $140.68 \pm 35.17$ & $270.70 \pm 114.89$ & $0.017^{* *}$ \\
\hline Dodecanoic acid & $16.23 \pm 5.46$ & $15.92 \pm 4.65$ & $15.29 \pm 7.29$ & $15.88 \pm 5.77$ & $17.10 \pm 4.89$ & $0.996^{*}$ \\
\hline Butanoic acid & $14.78 \pm 4.57$ & $17.29 \pm 2.06$ & $17.70 \pm 3.43$ & $16.44 \pm 4.41$ & $14.26 \pm 2.23$ & $0.694^{*}$ \\
\hline $\begin{array}{l}\text { Total } \\
\text { Carbonyl compounds }(\mathrm{mg} / \mathrm{L})\end{array}$ & $2219.94+249.55$ & $2761.06 \pm 905.77$ & $1529.40 \pm 238.13$ & $1133.74 \pm 212.11$ & $960.00 \pm 128.33$ & \\
\hline Acetaldehyde & $6.43 \pm 2.30$ & $6.54 \pm 0.61$ & $8.00 \pm 0.72$ & $8.15 \pm 1.04$ & $9.16 \pm 1.22$ & $0.131^{*}$ \\
\hline
\end{tabular}

tr. - traces. a-d Means within a line with different superscripts differ, $P<0.05$. Lack of a superscript indicates no significant difference, $P>0.05$.

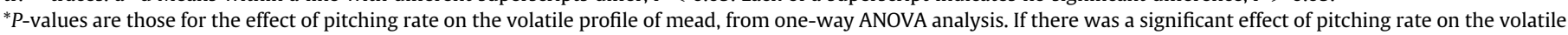
compounds data, then the means were compared with Tukey's test because equal variances could be assumed $(P>0.05$ by means of the Levene test).

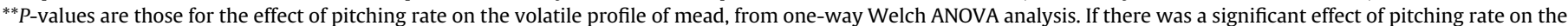

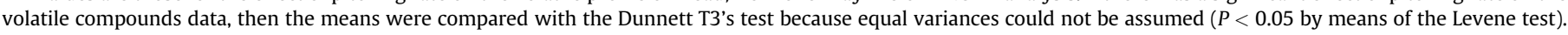

This compound is quantitatively the most important saturated aldehyde produced from sugar metabolism and ranges in a concentration from 10 to $75 \mathrm{mg} / \mathrm{L}$ (Swiegers et al., 2005). Acetaldehyde formation is known to be highly variable among strains of S. cerevisiae (Ugliano and Henschke, 2009), although in our study, both strains produced similar concentrations of this aldehyde. Some non-significant variation in acetaldehyde formation was observed among pitching rates. No relationship between the concentration of acetaldehyde and the inoculum size was observed for strain QA23, corroborating the results previously obtained by Erten et al. (2006) who had found no effect on this or other carbonyl compounds. On the contrary, ICV D47 formed less acetaldehyde at high pitching rates, as observed by Verbelen et al. (2009a).

In previous studies of the influence of volatile compounds on wine aroma, the Odour Activity Values (OAVs) were determined (Escudero et al., 2004; Vilanova et al., 2009, 2010). To evaluate the contribution of a certain chemical compound to the aroma of mead, the OAVs were calculated by dividing the concentration of each compound by its perception threshold. Only those compounds whose OAV was greater than 1 were considered to cause a significant contribution to the mead's aroma. It should be pointed out that individual OAVs do not account for the antagonistic or synergistic effects resulting from the perceptual interactions between different molecules present in wines, but they can serve as estimates for the potential contribution of each compound to the global aroma
(Vilanova et al., 2009). Those compounds, including odour descriptors and thresholds, are displayed in Table 5.

Fourteen of the twenty-seven volatile compounds quantified could have a valuable contribution to mead's aroma and flavour, because their concentrations were above their corresponding thresholds. The most aromatic meads were dependent not only on the fermentative strain but also on the pitching rate tested. More aromatic meads were fermented by $S$. cerevisiae strain QA23 at small inoculum sizes $\left(1.5 \times 10^{5} \mathrm{CFUs} / \mathrm{mL}\right.$ and $\left.10^{6} \mathrm{CFUs} / \mathrm{mL}\right)$. By contrast, the strain ICV D47 produced aroma compounds with higher OAVs than QA23 at high pitching rates $\left(10^{7} \mathrm{CFUs} / \mathrm{mL}\right.$ to $10^{8} \mathrm{CFUs} / \mathrm{mL}$ ). However, at low pitching rates, more interesting aroma compounds were released by both strains. In general, the lower the pitching rate, the higher the OAVs of the resulting mead, except for the mead fermented by ICV D47 at $10^{6} \mathrm{CFUs} / \mathrm{mL}$.

Ethyl hexanoate, ethyl octanoate and isoamyl acetate were the most powerful odourants detected in all of the meads. In fact, commercial wine strains produce variable amounts of esters, such as isoamyl acetate, ethyl hexanoate and ethyl octanoate, which have a potential impact on the aroma profile (Swiegers et al., 2005). Esters contribute favourably to aroma as a fruity characteristic. Indeed, ethyl octanoate and isoamyl acetate were two of the most abundant odourant compounds identified in the different meads. The OAV values of these compounds and of ethyl hexanoate decreased with increasing pitching rates. 
Table 5

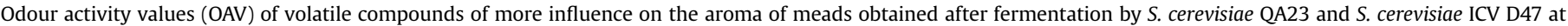
different pitching rates. Pitching rates: (PR1) $1.5 \times 10^{5}$ cells $/ \mathrm{mL}$, (PR2) $10^{6}$ cells $/ \mathrm{mL}$, (PR3) $10^{7}$ cells $/ \mathrm{mL}$, (PR4) $4 \times 10^{7}$ cells $/ \mathrm{mL}$ and (PR5) $10^{8}$ cells $/ \mathrm{mL}$.

\begin{tabular}{|c|c|c|c|c|c|c|c|c|c|c|c|c|}
\hline \multirow[t]{2}{*}{ Compounds } & \multirow[t]{2}{*}{ Odour descriptor $^{\mathrm{a}}$} & \multirow{2}{*}{$\begin{array}{l}\text { Odour threshold } \\
(\mu \mathrm{g} / \mathrm{L})^{\mathrm{a}}\end{array}$} & \multicolumn{5}{|l|}{ QA 23} & \multicolumn{5}{|l|}{ ICV D47 } \\
\hline & & & PR1 & PR2 & PR3 & PR4 & PR5 & PR1 & PR2 & PR3 & PR4 & PR5 \\
\hline 3-Methyl-1-butanol & Cheese; nail polish & 30000 & 5.60 & 4.45 & 4.28 & 3.92 & 4.10 & 5.01 & 4.66 & 4.21 & 4.87 & 5.51 \\
\hline 2-Methyl-1-propanol & Alcohol; bitter & 40000 & - & - & - & 1.03 & 1.56 & - & - & - & 1.04 & 1.87 \\
\hline Ethyl acetate & Solvent like; nail polish & 12300 & 2.21 & 2.03 & 1.92 & 2.21 & 2.86 & 1.85 & 2.09 & 1.74 & 1.46 & 1.65 \\
\hline Isoamyl acetate & Banana & 30 & 34.43 & 34.16 & 15.59 & 7.06 & 7.53 & 44.75 & 42.09 & 18.57 & 7.59 & 6.16 \\
\hline 2-Phenylethyl acetate & Flowery; roses & 250 & 2.40 & 2.02 & - & - & - & 2.75 & 2.28 & - & - & - \\
\hline Ethyl octanoate & Fruity; sweet & 5 & 95.44 & 107.11 & 46.47 & 27.19 & 19.17 & 78.72 & 87.48 & 63.21 & 45.03 & 34.48 \\
\hline Ethyl hexanoate & Fruity; aniseed & 14 & 24.64 & 19.12 & 8.28 & 5.10 & 3.78 & 15.17 & 16.27 & 12.01 & 6.79 & 5.56 \\
\hline Ethyl decanoate & Pleasant; soap & 200 & 1.52 & 1.43 & - & - & - & - & - & - & - & - \\
\hline Ethyl butyrate & Fruity; pineapple & 20 & 6.22 & 3.39 & 2.41 & 3.90 & 5.20 & 3.74 & 5.81 & 2.92 & 3.36 & 2.97 \\
\hline 4-Vinylphenol & Almond shell & 180 & 1.08 & - & - & - & - & - & - & - & - & - \\
\hline Octanoic acid & Fatty; rancid & 500 & 4.32 & 3.25 & 1.70 & 1.03 & - & 2.69 & 3.74 & 1.80 & 1.32 & - \\
\hline Decanoic acid & Fatty; soapy & 1000 & 1.03 & - & - & - & - & - & - & - & - & - \\
\hline Hexanoic acid & Cheese; sweaty & 420 & 1.43 & 1.35 & - & - & - & 1.00 & 1.07 & - & - & - \\
\hline Acetaldehyde & Fresh; green leaves & 500 & 14.24 & 12.55 & 19.61 & 15.81 & 15.06 & 12.86 & 13.08 & 15.99 & 16.31 & 18.32 \\
\hline Total & & & 195.11 & 192.89 & 103.73 & 68.71 & 61.15 & 170.87 & 181.08 & 123.90 & 89.33 & 78.70 \\
\hline
\end{tabular}

a Odour descriptors and odour threshold reported in the literature (Guth, 1997; Moreno et al, 2005; Siebert et al., 2005; Culleré et al., 2004; Escudero et al., 2004; Ferreira et al., 2000; Boidron et al., 1988; Czerni et al., 2008).

Scientific studies of mead production and quality are limited and are mainly concerned with the selection of yeasts for inoculation of honey-musts and with the impact of honey-must formulation on mead quality. This is the first study of the effects of inoculum size on the optimisation of mead production and final quality. Our results demonstrate that increasing pitching rates results in significant time savings in the fermentation process. However, caution should be taken, as an exaggerated inoculum could lead to lower production of desirable aromatic compounds. In addition to this quantitative analysis of the impact of strain selection and inoculum size on mead aroma, a complementary sensorial evaluation of the meads would yield further useful information for mead producers.

\section{Acknowledgements}

The research presented in this paper was partially funded by the Fundação para a Ciência e Tecnologia, (FCT) and by PTDC projects (contracts PTDC/AGR-ALI/68284/2006). A.P.P. is a recipient of a Ph.D. grant from FCT (SFRH/BD/45820/2008).

\section{References}

Aerny, J., 1996. Composés azotes des moûts et des vins. Revue Suisse de Viticulture, Arboriculture, Horticulture 28, 161-165.

Anklam, E., 1998. A review of the analytical methods to determine the geographical and botanical origin of honey. Food Chemistry 63 (4), 549-562.

Bogdanov, S., Martin, P., Lüllmann, C., 1997. Harmonised methods of the European Honey Commission. Apidologie 28, 1-59.

Boidron, J.N., Chatonnet, P., Pons, M., 1988. Influence du bois sur certaines substances odorantes des vins. Connaissance de la vigne et du vin 22, 275-294.

Carrau, F., Medina, K., Fariña, L., Boido, E., Dellacassa, E., 2010. Effect of Saccharomyces cerevisiae inoculum size on wine fermentation aroma compounds and its relation with assimilable nitrogen content. International Journal of Food Microbiology 143, 81-85.

Culleré, L., Escudero, A., Cacho, J., Ferreira, V., 2004. Gas chromatographyolfactometry and chemical quantitative study of the aroma of six premium quality Spanish aged red wines. Journal of Agricultural and Food Chemistry $52,1653-1660$.

Czerni, M., Christlbauer, M., Christlbauer, M., Fischer, A., Granvogl, M., Hammer, M., Hartl, C., Hernandez, N.M., Schieberle, P., 2008. Re-investigation on odour thresholds of key food aroma compounds and development of an aroma language based on odour qualities of defined aqueous odorant solutions. European Food Research and Technology 228, 265-273.

Decreto Lei n ${ }^{\circ} 214$ 2003, de 18 de Setembro de 2003, Diário da República I ${ }^{a}$ Série A

Erten, H., Tanguler, H., Cabaroglu, T., Canbas, A., 2006. The influence of inoculum level on fermentation and flavour compounds of white wines made from cv. Emir. Journal of Institute of Brewing 112 (3), 232-236.
Escudero, A., Gogorza, B., Melús, M.A., Ortín, N., Cacho, J., Ferreira, V., 2004. Characterization of the aroma of a wine from Maccabeo. Key role played by compounds with low odor activity values. Journal of Agricultural and Food Chemistry 52, 3516-3524.

Ferreira, V., López, R., Cacho, J.F., 2000. Quantitative determination of the odorants of young red wines from different grape varieties. Journal of Science and Food Agriculture 80, 1659-1667.

Filipe-Ribeiro, L., Mendes-Faia, A., 2007. Validation and comparison of analytical methods used to evaluate the nitrogen status of grape juice. Food Chemistry 100, 1272-1277.

Gomes, S., Dias, L.G., Moreira, L.L., Rodrigues, P., Estevinho, L., 2010. Physicochemical, microbiological and antimicrobial properties of commercial honeys from Portugal. Food and Chemical Toxicology 48, 544-548.

Guth, H., 1997. Quantification and sensory studies of character impact odorants of different white wine varieties. Journal of Agricultural and Food Chemistry 45 , 3027-3032.

Mateo, J.J., Jiménez, M., Pastor, A., Huerta, T., 2001. Yeast starter cultures affecting wine fermentation and volatiles. Food Research International 34, 307-314.

Mendes-Ferreira, A., Barbosa, C., Falco, V., Leão, C., Mendes-Faia, A., 2009. The production of hydrogen sulphide and other aroma compounds by wine strains of Saccharomyces cerevisiae in synthetic media with different nitrogen concentrations. Journal of Industrial Microbiology and Biotechnology 36, 571-583.

Mendes-Ferreira, A., Cosme, F., Barbosa, C., Falco, V., Inês, A., Mendes-Faia, A., 2010 Optimization of honey-must preparation and alcoholic fermentation by Saccharomyces cerevisiae for mead production. International Journal of Food Microbiology 144, 193-198.

Moreno, J.A., Zea, L., Moyano, L., Medina, M., 2005. Aroma compounds as markers of the changes in sherry wines subjected to biological ageing. Food Control 16 , 333-338.

Navrátil, M., Šturdík, E., Gemeiner, P., 2001. Batch and continuous mead production with pectate immobilised, ethanol-tolerant yeast. Biotechnology Letters 23, 977-982.

Oliveira, J.M., Faria, M., Sá, F., Barros, F., Araújo, I.M., 2006. C6-alcohols as varietal markers for assessment of wine origin. Analytica Chimica Acta 563, 300-309.

Organisation International de la Vigne e du Vin, 2006. Recueil des méthodes internationales d'analyse des vins et des mouts. OIV, Paris.

O'Connor-Cox, E.S., Ingledew, W.M., 1991. Alleviation of the effects of nitrogen limitation in high gravity worts through increased inoculation rates. Journal of Industrial Microbiology 7, 89-96.

Pereira, A.P. Dias, T. Andrade, J. Ramalhosa, E, Estevinho, L.M., 2009. Mead production: selection and characterization assays of Saccharomyces cerevisiae strains. Food and Chemical Toxicology 47, 2057-2063.

Pires, J., Estevinho, M.L., Feás, X., Cantalapiedra, J., Iglesias, A., 2009. Pollen spectrum and physico-chemical attributes of heather (Erica sp.) honeys of north Portugal. Journal of the Science of Food and Agriculture 89, 1862-1870.

Ribéreau-Gayon, P., Dubourdieu, D., Donèche, B., Lonvaud, A., 2000. Handbook of Enology. In: The Microbiology of Wine and Vinifications, vol. 1. John Wiley \& Sons Ltd, Chichester, England.

Riesenberg, D., Guthke, R., 1999. High-cell-density cultivation of microorganisms. Applied Microbiology and Biotechnology 51, 422-430.

Sancho, M.T., Muniategui, S., Sánchez, P., Huidobro, J.F., Simal, J., 1991. Mieles del Pais Vasco, XI: Evaluación de los distintos tipos de cenizas. Anales de Bromatologia XLIII-4, 311-324.

Siebert, T.E., Smyth, H.E. Capone, D.L., Neuwöhner, C., Pardon, K.H Skouroumounis, G.K., Herderich, M.J., Sefton, M.A., Pollnitz, A.P., 2005. Stable isotope dilution analysis of wine fermentation products by HS-SPME-GC-MS Analytical and Bioanalytical Chemistry 381, 937-947. 
Sroka, P., Tuszyński, T., 2007. Changes in organic acid contents during mead wort fermentation. Food Chemistry 104, 1250-1257.

Swiegers, J.H., Bartowsky, E.J., Henschke, P.A., Pretorius, I.S., 2005. Yeast and bacterial modulation of wine aroma and flavour. Australian Journal of Grape and Wine Research 11, 139-173.

Ugliano, M., Henschke, P.A., 2009. Yeasts and wine flavour. In: MorenoArribas, M.V., Polo, M.C. (Eds.), Wine Chemistry and Biochemistry. Springer Science+Business Media, LLC, pp. 313-392.

Verbelen, P.J., Van Mulders, S., Saison, D., Van Laere, S., Delvaux, F. Delvaux, F.R., 2008. Characteristics of high cell density fermentations with different lager yeast strains. Journal of the Institute of Brewing 114 (2), 127-133.
Verbelen, P.J., Dekoninck, T.M.L., Saerens, S.M.G., Van Mulders, S.E., Thevelein, J.M., Delvaux, F.R., 2009a. Impact of pitching rate on yeast performance and beer flavour. Applied Microbiology and Biotechnology 82, 155-167.

Verbelen, P.J., Saerens, S.M.G., Van Mulders, S.E., Delvaux, F., Delvaux, F.R., 2009b. The role of oxygen in yeast metabolism during high cell density brewery fermentations. Applied Microbiology and Biotechnology 82, 1143-1156.

Vilanova, M., Genisheva, Z., Bescansa, L., Masa, A., Oliveira, J.M., 2009. Volatile composition of wines from cvs. Blanco lexítimo, Agudelo and Serradelo (Vitis vinifera) grown in Betanzos (NW Spain). Journal of the Institute of Brewing 115 (1), 35-40.

Vilanova, M., Genisheva, Z., Masa, A., Oliveira, J.M., 2010. Correlation between volatile composition and sensory properties in Spanish Albariño wines. Microchemical Journal 95, 240-246. 